\title{
SYSTEMIC APPROACHES IN REVITALIZATION OF SEMARANG OLD CITY HERITAGE SITE: FROM NEGLECTED AREA TO TOURISM DESTINATION
}

\author{
DOI: 10.18485/arh_pt.2020.7.ch38
}

\author{
_ Bintang Noor Prabowo \\ Department of Civil and Environmental Engineering, Norwegian \\ University of Science and Technology (NTNU), bintang.n.prabowo@ntnu.no
}

\author{
_ Alenka Temeljotov Salaj \\ Department of Civil and Environmental Engineering, Norwegian \\ University of Science and Technology (NTNU), alenka.temeljotov-salaj@ntnu.no
}

\begin{abstract}
Many heritage areas, with different typologies, problems, and existing levels of decays, in several countries, were left abandoned and causing various economic, social, and urban complications. Some typologies of urban heritage areas often found in previous studies are ex-colonial settlement, industrial cultural-heritage, park, ancient cemetery, etc. The typical problems that repeatedly occurred, such as decays, depreciation of land value, and safety/security issues, show that although located in different places, urban heritage areas might face the same glitches. The existing condition of those places are ranging from relatively well preserved, regular, medium severe, severely damaged, and even totally damaged, thus needed to be taken care of using different conservation approaches; preservation, reconstruction, restoration, and (or) adaptation.
\end{abstract}

Despite the current conditions, such sites are nowadays considered as an essential part of humans' and cities' history. Some of those heritage sites face challenges in gaining sustainable conservation in cultural, environmental, social, economic, and territorial aspects. They usually have been left behind by their "enablers" that previously led the growth of these areas, not to mention the specific and latent characteristics of the urban heritage area that could be very different from today's urban ecosystem.

One current case worth to be observed is Semarang Old City (Kota Lama Semarang), a previously abandoned ex-Dutch colonial towns located in Java Island, Indonesia, that shows interesting trends of ups and downs throughout this last century. This urban heritage area, being left abandoned for decades, finally emerges as a new tourism destination in Central Java province within the last couple of years. The booming visits of tourists and enthusiasts is a remarkable phenomenon to be studied since numbers of researches on the same cases in other countries show various impacts regarding the sustainability of such urban heritage areas. This article aims to identify the strategic approach in the revitalization of the Semarang Old City urban heritage area using six critical steps from the Historic Urban Landscape Approach and principles of Urban Facility Management.

METHODOLOGY: This qualitative study uses literature research and observational technique to obtain information and conduct a comprehensive analysis of the phenomenon; RESULTS: the matriculation table resulted in this article is a useful resource to understand the strategic approach in the management of urban heritage conservation, so that the stakeholders of any specific urban heritage in general, and Kota Lama Semarang in specific, could benefit from the knowledge, and therefore contribute more according to their individual and collective roles; TYPE OF PAPER: Viewpoint paper.

KEYWORDS _ urban heritage, conservation, revitalization,

urban facility management, historic urban landscape 


\section{INTRODUCTION}

After the national and local policy started to take a side on the conservation of Semarang Old City (Kota Lama) area by the early 1990s, the district slowly gained attention from its stakeholders, after being abandoned for decades due to several reasons. Besides lack of infrastructures and known as a dangerous area to be visited, this area also often faced a periodic tidal flood, causing damages to the heritage buildings. Some of the buildings even collapsed due to deterioration of their wooden structures, or simply because intentionally left untreated properly by their owners (B. N. Prabowo and Harsritanto 2018).

By the issuance of Mayor Decree No.646/50/1992, as an operational, legal document for National Act. No 5 of 1992 on Heritage Artefact, the municipality of Semarang began to conduct a systemic approach to preserve historical buildings in the city, including the Kota Lama area, by creating a list of protected heritage buildings. On the national level, within the next two decades, the act was renewed with a more comprehensive regulation with the ratification of National Act no. 11 of 2010 on Heritage.

\section{A brief history of Kota Lama Semarang}

The Dutch colony history in Central Java began with the relocation of the representative office of the Vereenigde Oost-indische Compagnie (VOC), a large company formed by the government from a merger of a couple of Dutch trading-companies, from Jepara to Semarang in 1708. As a reward for defeating the Trunojoyo rebel in Madura, the kingdom of Mataram granted the VOC the right to operate in the Semarang harbor region by the end of 1677, in compliance with the agreement between VOC and Amangkurat II. Next to the resident's house, on the side of the Kali Semarang, a building permit for the settlement was issued. VOC was then subsequently given the monopoly on duty-free trade in rice and sugar and the right to inhabit most of the territory of Semarang (B. N. et al Prabowo 2019).

The earliest proof of Kota lama Semarang's presence was seen on the map of PAAN van het Fort en Omleggende Cituatie van Samarangh as a fortress, dating back to 1695 (Figure 1). The location was situated on Kali Semarang's east side. VOC had a large number of soldiers and staff, according to Fransçois Valentijn, who was in charge of trade with the locals. In the shape of five edged stars, the colony settlement was reinforced by a wood plank on each edge: Zeeland, Amsterdam, Utrecht, Raamsdonk, and Bunschoten (Hendro 2017). The cluster eventually became known as De Vijfhoek van Samarangh.
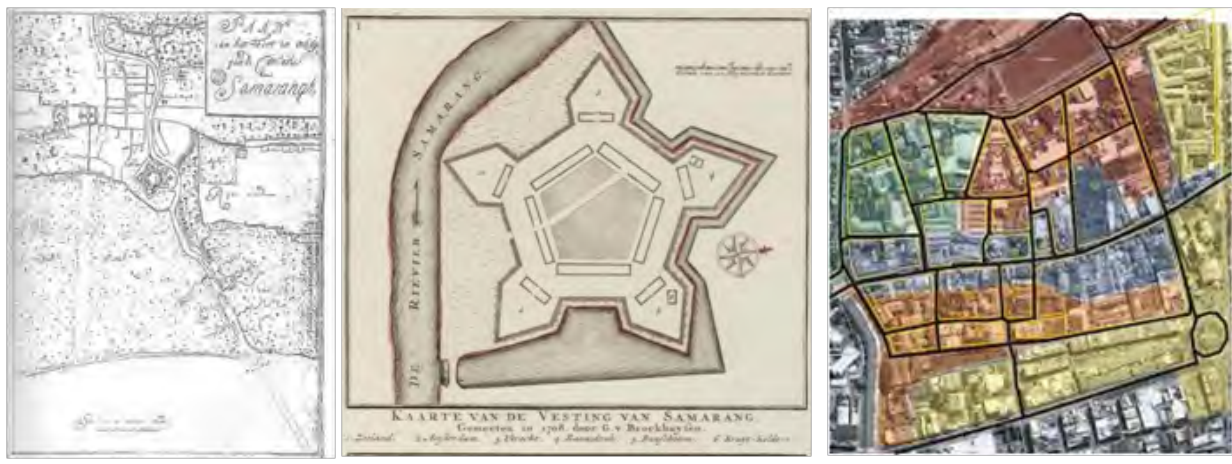

_ Figure 1: Evolution of Semarang Old City (Kota Lama) Maps (source: https://www.researchgate.net/ publication/339105098_Historic_urban_landscape_HUL_approach_in_Kota_Lama_Semarang_mapping_ the_layer_of_physical_development_through_the_chronological_history, and https://www.connective-cities.net/fileStorage/Veranstaltungen/ Projektwerkstatt_Jakarta/Dokumenten/T1-2_Presentasi_Kota_Lama_UCLG_180717.pdf; access date: 05.05.2020) 
There were not many construction activities in this part of town after the Second World War. Following the Republic of Indonesia's Declaration of Independence in 1945, this region started to deteriorate gradually. In 1910, the old bridge named de Zuiderport burg or Gouvernementsburg was rebuilt and added with a new identical bridge in the 1980 s, following a new policy of one-way route circling around de Heerenstraat.

Due to the local flood caused by the increase in water surface level during some periods, especially during rainy seasons, the degradation of this area worsened every year. It used to be inconvenient and dangerous to walk through this area at night before the year 2000 , as this abandoned section of the city was notorious for its criminal and homeless activities, after the commercial functions progressively left the old town of Semarang to the new center of Semarang (B. N. Prabowo and Harsritanto 2018). Despite those conditions, the Mayor of Semarang released policy of Mayor Decree No.646/50/1992 on conservation of heritage buildings in Semarang, including those which scattered inside the Old City, as a manifestation of higher government regulation (UU No. 5, 1992 on Heritage Artefact)

Between 1999-2000, to address the flood crisis, the Semarang government undertook the construction of Polder Tawang, a pond or water retention system fitted with pumps to control the flood if needed. Used for different purposes earlier, the site of this Tawang polder used to be a 1.3-hectare public space (Wicaksono 2016). The polder architecture was meant to replicate Kota Lama Semarang 's environment as it is situated between Tawang Station and Noorderwalstraat. Many younger generations regarded this Tawang Polder as an old artifact from the Nederlandsch Indische period, after twenty years of its first operational; a misunderstanding with stakeholder mix-response.

UNESCO has already identified the Old City of Semarang in the Tentative List of emerging World Heritage by 2017 , a big step towards the complete acceptance of being promoted as a World Heritage by the WHC (B. N. Prabowo and Harsritanto 2018). Since that, a major renovation is being carried out in Kota Lama Semarang, but many experts and scholars are concerned about the originality of the Old City as the gentrification seems to be targeted solely for tourism purposes, with less heritage conservation concern.

Some changing strategic approaches were taken in the effort of preservation, reconstruction, restoration, and adaptation during a relatively long period of time with different leadership. This article aims to identify those strategies applied in the gentrification of the urban Heritage from the Historic Urban Landscape approach and (urban) facility management point of view.

\section{METHODOLOGY}

Initially, the study began with a historical data collection to support the first step of the Historic Urban Landscape approach through literature survey, secondary sources, archival study, interviews, and field observation to obtain information and conduct a comprehensive analysis of the phenomenon. A qualitative data analysis software is used to code, classify, and analyze the data descriptively to understand better the strategic approach taken in Semarang Old City revitalization from the HUL approach and (urban) FM perspectives.

\section{RESULT AND DISCUSSION}

The study shows that the strategic approaches taken in managing Semarang Old City heritage area are taken intuitively without addressing the UNESCO Recommendation on the Historic Urban Landscape (HUL) approach. The Historic Urban Landscape assessment framework from the work of Veldpaus and Roders (2013) was used in this study. The participation of people and civic society was seemingly set to minimal, although all elements of (urban) Facility Management and values assessment were already taken into consideration. It will be challenging for Kota Lama Semarang to be promoted as a World Heritage site if the Historic Urban Landscape approach is not addressed 
properly (as shown in table 1). However, the dwellers gain benefits from the blooming of tourism after major urban gentrification was taken.

- Table 1: The Historic Urban Landscape Assessment in Kota Lama Semarang (inherited from the HUL assessment framework by Veldpaus \& Roders)

\begin{tabular}{|l|c|c|c|c|c|ccc}
\hline & \multicolumn{4}{|c|}{ Traditional Values } & \multicolumn{2}{c}{ Community Values } & \multicolumn{2}{c}{ Process Values } \\
\cline { 2 - 8 } & Aesthetical & Age & Historic & Scient fic & Social & Political & Economic & Ecological \\
\hline A. Map resources & 1 & 1 & 1 & 1 & 3 & 0 & 3 & 1 \\
\hline $\begin{array}{l}\text { B. Reach consensus on } \\
\text { what to protect }\end{array}$ & 0 & 4 & 3 & 1 & 3 & 0 & 1 & 1 \\
\hline C. Asses vuinerability & 1 & 1 & 1 & 1 & 1 & 0 & 3 & 1 \\
\hline $\begin{array}{l}\text { D. Integrate A, B, C in } \\
\text { urban management }\end{array}$ & 1 & 1 & 1 & 1 & 3 & 1 & 1 & 1 \\
\hline E. Prioritize action & 3 & 3 & 1 & 1 & 3 & 1 & 3 & 1 \\
\hline F. Define partnership & 1 & 1 & 1 & 1 & 3 & 0 & 3 & 1
\end{tabular}

As an asset for the city, Kota Lama Semarang is already listed in the tentative list of World Heritage by WHC and UNESCO. A strict requirement should be fulfilled in order to be promoted as a World Heritage due to its uniqueness and outstanding universal value as one of the human civilization traces during the colonial era. Strategic approaches have already been implemented in multiple phases, and as the urban heritage area nourished with tourism, a systematic assessment was taken by this study to identify the strategic approach from the Historic Urban Landscape (HUL) approach and (urban) facility management perspectives.

\section{Cultural Heritage Management of Semarang Old City}

Cultural Heritage Management (CHM) is "a heritage protection mechanism that coordinates and integrates the function of a heritage site with the primary aim of preserving the importance of the site as specified by designation requirements, government entities or other stakeholders, experts from different shades and other people with valid interests in the site" (Mason et al., 2003 in Hasbollah, (2015)). The essence of strategic planning in revitalizing Kota Lama Semarang is not a straightforward strategy, but more likely to include multiple facets and stakeholders in the area. In specific, when dealing with cultural Heritage that has visible and intangible elements, a more cyclical process ought to be undertaken, which opens up opportunities for input and appraisal from multiple points of view. The key driver in tackling the ever-changing complexities of urban planning is the establishment of a consistent long-term strategy as a roadmap to taking short-term action (Rafidee Bin Hasbollah 2015). A top-down conservation approach that still governs the serial processes of urban patrimony gentrification in Kota Lama Semarang, while some focus group discussions with academics and specialists still take place in the creation of the master plan. Typical issues in Indonesia are lack of popular interest and political activity. In some cases, the influential position of the consultant as the messenger of the vision of authority was criticized as neglecting the expectations of the dwellers of the Old City. After, such a consultant's lack of conservation expertise resulted in the "Disneyfication" and needless ornamentation across the heritage region.

The definition of Cultural Heritage Management has ramifications for site administrators and heritage practitioners, according to Altenburg (2010). Management initiatives that effectively include site management, a multidisciplinary team with a variety of expertise, realistic and conceptual thought, resilience, and the continued engagement and engagement of the local community are required for successful execution. Through the Mayor Decree No.12 in 2007, a special body, namely BPK2L (Badan Pengelola Kawasan Kota Lama/ Old City Area Management Body) was established as a non-structural institution with responsibilities to manage, develop, and optimize the potential of the Kota Lama Semarang area, including planning, monitoring, supervising, and controlling the development of the protected urban heritage zone. BPK2L, with a multi sectors member, was supposed to become an influential body for the conservation and revitalization conducted in the site, but 
most decisions were made at the municipal level.

_ Table 2: Distribution of strategic approach in Kota Lama Semarang

\begin{tabular}{|c|c|c|c|c|}
\hline Element & Values & Strategy & Approach & $\begin{array}{c}\text { FM } \\
\text { Level }\end{array}$ \\
\hline \multirow[t]{8}{*}{ People } & \multirow{8}{*}{$\begin{array}{l}\text { Social } \\
\text { Political }\end{array}$} & \multirow{4}{*}{$\begin{array}{l}\text { Improvement of } \\
\text { human resources } \\
\text { within the } \\
\text { bureaucratic system } \\
\text { and the dwellers }\end{array}$} & Improve a clean and efficient government. & $\mathrm{S}, \mathrm{T}, \mathrm{O}$ \\
\hline & & & Friendly officers/ field operators & 0 \\
\hline & & & $\begin{array}{l}\text { Improve the security to increase comfort and } \\
\text { safety }\end{array}$ & $\mathrm{O}$ \\
\hline & & & Regulation of informal sectors & $\mathrm{T}$ \\
\hline & & \multirow{4}{*}{$\begin{array}{l}\text { Improvement of } \\
\text { Public-Private-People } \\
\text { Partnership }\end{array}$} & Civic engagement/ public participation & $\mathrm{S}, \mathrm{T}, \mathrm{O}$ \\
\hline & & & Transparent government/ policy & $\mathrm{S}, \mathrm{T}$ \\
\hline & & & Ease of permit obtaining & $\mathrm{S}, \mathrm{T}, \mathrm{O}$ \\
\hline & & & $\begin{array}{l}\text { Improve Public-Private Partnership (PPP) \& } \\
\text { Public-Private-People Partnership (PPPP) }\end{array}$ & $\mathrm{S}, \mathrm{T}, \mathrm{O}$ \\
\hline \multirow[t]{12}{*}{ Process } & \multirow[t]{3}{*}{ Ecological } & \multirow{3}{*}{$\begin{array}{l}\text { Improvement of Flood } \\
\text { and Drainage } \\
\text { Management }\end{array}$} & Flood Prevention and Drainage Masterplan & $\mathrm{S}, \mathrm{T}$ \\
\hline & & & Water retention polder & $\mathrm{T}, \mathrm{O}$ \\
\hline & & & Scheduled maintenance & $\mathrm{O}$ \\
\hline & \multirow[t]{3}{*}{ Economic } & \multirow{3}{*}{$\begin{array}{l}\text { Incentives and ease of } \\
\text { investment }\end{array}$} & Financial management & $\mathrm{S}, \mathrm{T}$ \\
\hline & & & Tax deduction and relieves & $\mathrm{S}, \mathrm{T}, \mathrm{O}$ \\
\hline & & & Reduction of building permit cost & $\mathrm{T}, \mathrm{O}$ \\
\hline & \multirow[t]{6}{*}{ Political } & \multirow{6}{*}{$\begin{array}{l}\text { Management of } \\
\text { historic city }\end{array}$} & Internal stakeholder and bureaucracy & $\mathrm{S}, \mathrm{T}, \mathrm{O}$ \\
\hline & & & BPK2L & $\mathrm{S}, \mathrm{T}, \mathrm{O}$ \\
\hline & & & Coordination with Provincial and National level & $\mathrm{S}, \mathrm{T}$ \\
\hline & & & Pro heritage policy & $\mathrm{S}$ \\
\hline & & & World heritage promotion & $\mathrm{S}, \mathrm{T}, \mathrm{O}$ \\
\hline & & & Monitoring and Evaluation & $\mathrm{S}, \mathrm{T}$ \\
\hline \multirow[t]{9}{*}{ Place } & \multirow{9}{*}{$\begin{array}{l}\text { Aestheti } \\
\text { c } \\
\text { Historic } \\
\text { Age } \\
\text { Scientifi } \\
\text { c }\end{array}$} & \multirow{5}{*}{$\begin{array}{l}\text { Urban Heritage } \\
\text { Development }\end{array}$} & Improve building regulation & $\mathrm{S}$ \\
\hline & & & Improve supervision & 0 \\
\hline & & & List of heritage buildings and places & $\mathrm{S}, \mathrm{T}, \mathrm{O}$ \\
\hline & & & Masterplan of Kota Lama Semarang & $\mathrm{S}$ \\
\hline & & & Guideline of renovation \& conservation & $\mathrm{S}, \mathrm{T}$ \\
\hline & & \multirow[t]{4}{*}{ Urban infrastructure } & Urban utilities & $\mathrm{S}, \mathrm{T}$ \\
\hline & & & Street ornaments & $\mathrm{S}, \mathrm{T}, \mathrm{O}$ \\
\hline & & & Improvement of existing parks & $\mathrm{T}, \mathrm{O}$ \\
\hline & & & Improvement of walkability & $\mathrm{S}, \mathrm{T}, \mathrm{O}$ \\
\hline \multirow{4}{*}{$\begin{array}{l}\text { Technolog } \\
\text { y }\end{array}$} & \multirow{4}{*}{$\begin{array}{l}\text { Social } \\
\text { Scientifi } \\
\text { c } \\
\text { Ecological }\end{array}$} & \multirow[t]{4}{*}{ Usage of technologies } & Official website & $\mathrm{T}, \mathrm{O}$ \\
\hline & & & Sensors and CCTV & $\mathrm{O}$ \\
\hline & & & Command center & $\mathrm{T}, \mathrm{O}$ \\
\hline & & & Application of smart city & $\mathrm{S}, \mathrm{T}, \mathrm{O}$ \\
\hline
\end{tabular}

Numbers of strategies and approaches were taken along the period of different leadership and a couple of trials and errors in conducting conservation of heritage buildings. The shifting paradigm in Urban Heritage conservation from treating the building as monuments to be preserved into a more holistic approach with the latest UNESCO recommendation on the HUL approach brings consequences in minor and major adjustments within the conservation of Kota Lama Semarang.

Therefore, the importance of cultural value qualities and the role of heritage stakeholders in decision-making processes were included in CHM. However, as mentioned earlier, there is a shortfall in the application of the Cultural Heritage Management process in the conservation of heritage buildings. Because of that, this issue needs to be addressed, and a new conservation paradigm is being proposed. A facility management perspective will, therefore, be proposed due to its familiarity with the practice of building maintenance.

\section{Traditional Values}

Assessment criteria towards traditional values (aesthetical, age, historical, scientific) significantly showed that the age of heritage building reach the highest score due to the ease to obtain data 
regarding building age and clear guidance from the National Act on Heritage article 5, which stated that one of the criteria to be listed as a heritage, the age of the building has to already reach a minimum 50 years of existence. There is no dispute on this matter amongst the stakeholders. Another value that raised a high consensus, both on tangible and intangible, is the historic value embedded in the buildings or other cultural heritages. It is interesting to find out that aesthetic value is not becoming a leading factor in traditional values, while it is, at the same time, considered important to determine action priority. One of the explanations is that the aesthetic factor could be very subjective from one to another person or group.

Generally, resource mapping, vulnerability assessment, and defining partnerships in the management of Semarang Old City heritage area have not yet been conducted in a comprehensive manner. Physical aspects as tangible attributes contributed to the bigger portion of the short-term development plan. A more interesting Public-Private Partnership (PPP) or Public Private People Partnership (PPPP) scheme, as shown by Salaj et al. (2018), could be applied as new alternative models in defining partnerships inside the conservation area.

The integration of resource mapping, consensus reaching, and vulnerability assessment within a larger urban context also mostly focused on the tangible aspect. Recently, the chief of BPK2L, who is also the Vice Mayor of Semarang City, announced that the area of Old Semarang City had been stated as a National Heritage Site by the Ministry of Education and Culture of the Republic of Indonesia. The usage of the term Old Semarang City (instead of Semarang Old City) indicated that another three historical areas (Kauman, Kampung Melayu, and the China Town) are simultaneously set together with Semarang Old City (Kota Lama) to form an entire Old Semarang City urban heritage site.

\section{Community Values}

Social and political values assessment in Kota Lama Semarang resulted in a very contrast output. All assessment checkpoint on social values shows that a large portion of attention is given to both tangible physical aspects and non-physical cultural aspects (intangible). On the contrary, the study reveals that political aspects are not becoming the dominant factor of the community values.

From the interview with several local historians, it is evident that although the acceleration of urban heritage gentrification in Semarang Old City is a political decision taken by the Mayor of Semarang municipality and the President of the Republic of Indonesia (through the Ministry of Public Works), the mapping of resources, consensus achievement, vulnerability assessment, and partnership defining the process, have not been exploited politically. Only the action prioritization and integration of the first three-factor in urban management context being assessed as politic-related values, especially the tangible ones. Political decisions such as tax benefits and incentives towards the property owners on the urban heritage area also have strong relationships with economic values.

\section{Process Values}

Within urban facility management discipline, "process" is an important part, along with "people" and "place," to enhance an efficient and sustainable city. Table 1 indicates that economic values are an important aspect in the development of urban heritage areas such as Kota Lama. Without economic activity, an urban heritage area will not be sustainable in the long run. After being stagnant for decades, Semarang Old City gaining its momentum back toward economic balance, following the successful revitalization of the area.

Ecological values seem to be still focusing on the two big issues on the area; flood controlling and emission reduction. The plan of creating "slow traffic" inside the conservation area is often criticized as an ambiguous decision. New parking management by creating multiple parking spots on the district's periphery is considered preferable for the convenience and the wellbeing of the dwellers and tourists in the conservation site. 

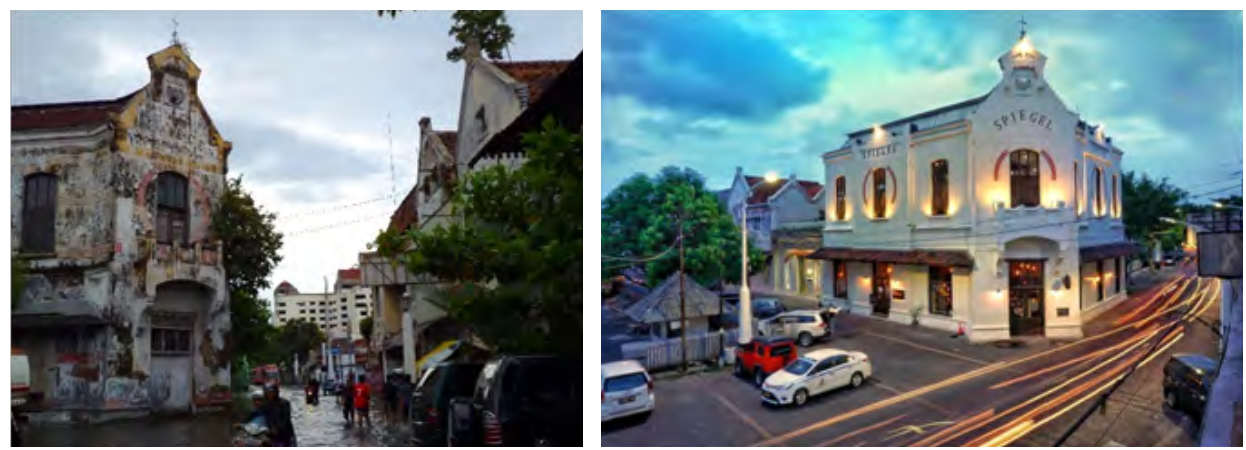

_ Figure 2: Semarang Old City (Kota Lama) before and after urban heritage gentrification (source: https:// bambangpriantono.wordpress.com/2013/02/23/catatan-wisata-banjir-hari-ini/ and https://cjtb.or.id/ listing/semarang-old-town-charming-old-time-heritage-atmosphere/; access date: 05.05.2020)

\section{CONCLUSIONS}

The conservation of Kota Lama Semarang had a multiple-phase evolution with different approaches. It is evident that the planning and development of the urban heritage area were not entirely following UNESCO Recommendation on the Historic Urban Landscape, which is understandable since the recommendation itself was issued in 2011 and still in its establishment phase. The conservation movement in the Semarang Old City began in 1992, following the ratification of the National Act on heritage protection. More than 50 percent of the heritage buildings in Semarang were listed and clustered in the Kota Lama Semarang heritage area.

Critiques were addressed to the authority due to its exclusivity in the top-down model of decision making, which resulted in a couple dispute and misunderstanding during the gentrification process. A phenomenon of "Disneyfication" by adding too much (and unrelated) accessories was one of clear signs that the authority in charge was not fully aware of the importance of preserving the significance and originality of the heritage area. By not entirely following the guidance of the Historic Urban Landscape Approach and the critical steps of HUL, the prospect of being listed as a World Heritage by the UNESCO is going to be very limited.

However, the Semarang Old City has now gradually back to life and find its new direction, despite the academic and technical debates on the rights or wrongs in the policymaking. It is the duty of bureaucracy, academics, and other stakeholders to enhance and guide this spirit of betterment by systematically involved in the conservation process in accordance with the vision of Kota Lama Semarang to become one of the World Heritage sites in Indonesia.

\section{REFERENCES}

\footnotetext{
_ Altenburg, K. 2010. "Values-Based Management at Cultural Heritage Sites." Amoeda, R. Lira, S. and Pinheiro, C.(Eds.) Heritage.

- Hendro, Eko Punto. 2017. "Study of the Outstanding Universal Values (OUV) to Achieve the Semarang Old Town as the World Heritage City." Advanced Science Letters 23(10): 10002-4.

_ Prabowo, Bintang Noor; et al. 2019. "Historic Urban Landscape (HUL) Approach in Kota Lama Semarang: Mapping the Layer of Physical Development through the Chronological History." In IOP Conf. Series: Earth and Environmental Science; ICSADU 2019, Semarang: IOP Publishing.

_ Prabowo, Bintang Noor, and Bangun IR Harsritanto. 2018. "KOTA LAMA SEMARANG MENUJU STATUS PUSAKA DUNIA UNESCO: APA ITU STATUS WORLD HERITAGE?" MODUL.
} 
- Rafidee Bin Hasbollah, Hasif. 2015. "A Conceptual Framework for Conserving Heritage Buildings in Malaysia from the Perspective of Facilities Management." International Journal of Economics and Financial Issues (5): 45-51. http:www.econjournals.com (September 1, 2020).

- Salaj, Alenka Temeljotov, Athena Roumboutsos, Peter Verlič, and Bojan Grum. 2018. "Land Value Capture Strategies in PPP - What Can FM Learn from It?" Facilities.

- Veldpaus, Loes, and Ana Pereira Roders. 2013. "Historic Urban Landscapes : An Assessment Framework Part II." In 29th Conference of Sustainable Architecture for a Renewable Future (PLEA 2013), Munich, Germany, 1-5.

- Wicaksono, Fajar B. 2016. "Urban Drainage and Options for Urban Polder Development for UNESCO Heritage Kota Lama, Semarang, Central Java, Indonesia." 